\title{
PELUANG ANAK-ANAK BEKERJA MENURUT KARAKTERISTIK ANAK, RUMAH TANGGA, DAN KEPALA RUMAH TANGGA DI BALI
}

\author{
I Made Juli Ardana ${ }^{1^{*}}$ \\ ${ }^{1}$ BPS Provinsi Bali, Indonesia \\ *e-mail: juliardan@bps.go.id
}

\begin{abstract}
Abstrak
Penelitian ini bertujuan mendapatkan gambaran mengenai karakteristik pekerja anak di Bali tahun 2020. Latar belakang munculnya pekerja anak sangat penting untuk diketahui, agar kebijakan yang diambil dalam pengentasan pekerja anak tepat sasaran. Data yang digunakan bersumber dari Susenas Maret 2020 dan metode analisis yang digunakan adalah analisis deskriptif dan regresi logistik biner. Analisis deskriptif digunakan untuk mendapatakan gambaran umum kondisi pekerja anak. Analisis regresi logistik biner digunakan untuk menguji variabel-variabel yang berpengaruh terhadap munculnya pekerja anak. Variabel karakteristik anak diwakili oleh usia dan jenis kelamin anak, variabel rumah tangga direpresentasikan oleh wilayah tempat tinggal, penerimaan bantuan pangan tunai, penerimaan kredit, kelompok pengeluaran, dan jumlah anggota rumah tangga. Variabel karakteristik kepala rumah tangga dicerminkan oleh umur, jenis kelamin, status perkawinan, jam kerja, status disablilitas, pendidikan dan status bekerja kepala rumah tangga. Temuan dalam penelitian ini menunjukkan bahwa klasifikasi daerah tempat tinggal, jenis kelamin anak, usia anak, usia kepala rumah tangga, status perkawinan kepala rumah tangga, status disabilitas kepala rumah tangga, tingkat pendidikan kepala rumah tangga, dan penerimaan bantuan pangan tunai rumah tangga berpengaruh signifikan terhadap munculnya pekerja anak. Pekerja anak di Bali, dua pertiga di antaranya berjenis kelamin perempuan. Persentase pekerja anak pada kelompok pengeluaran 40 persen terbawah jauh lebih tinggi daripada pekerja anak pada kelompok pengeluaran 20 persen teratas. Anak-anak perempuan, memiliki kepala rumah tangga disabilitas, status perkawinan kepala rumah tangga tidak kawin/cerai, kepala rumah tangga berpendidikan SD, dan rumah tangganya menerima bantuan pangan berpeluang lebih besar untuk bekerja.
\end{abstract}

Kata kunci: Eksploitasi Anak; Kemiskinan Absolut; Pekerja Keluarga; Pekerja Anak

\begin{abstract}
This study aimed to obtain an overview of the characteristics of child labor in Bali in 2020. The background for the emergence of child labor is essential so that policies taken to reduce child labor are right on target. The data used are sourced from the March 2020 Susenas, and the analytical methods used are descriptive analysis and binary logistic regression. Descriptive analysis is used to get an overview of the conditions of child labor. Binary logistic regression analysis was used to examine the variables that influence the emergence of child labor. The age and sex of children represent variable characteristics of children. Household variables are represented by the area of residence, receipt of cash food assistance, credit receipts, expenditure groups, and the number of household members. The characteristic variables of the head of the household are reflected by age, gender, marital status, working hours, disability status, education, and working status of the head of the household. The study findings indicate that the classification of the residence area, the child sex, the age of the child, the age of the head of the household, the marital status of the head of the household, the disability status of the head of the household, the education level of the head of the household, and the receipt of household cash food assistance have a significant effect, against the emergence of child labor. Of the child laborers in Bali, two-thirds of them are female. The percentage of child labor in the bottom 40 percent expenditure group is much higher than that of children in
\end{abstract}


the top 20 percent. Girls, having a head of household with a disability, the marital status of the head of the household is not married/divorced, the head of the household has an elementary education, and the household that receives food assistance has a greater chance of working.

Keywords: Children Exploitation; Absolute Poverty; Family Worker; Child Labor

This is an open access article under the CC BY-SA license.

Copyright (C) 2021 by Author. Published by Universitas Pendidikan Ganesha.

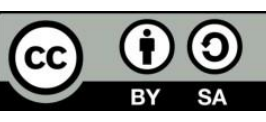

\section{PENDAHULUAN}

Anak-anak merupakan aset sumber daya manusia di masa depan untuk membangun negara, melindungi hak-hak anak untuk mendapatkan pendidikan, kesehatan, dan berkembang sesuai dengan usianya agar kelak dapat menjadi warga yang produktif (Badan Pusat Statistik, 2010). Menjamin anak-anak mendapatkan hakhaknya berarti menyiapkan sumber daya manusia yang unggul untuk masa depan negara. Fakta bahwa masih terdapat anakanak yang bekerja merupakan sebuah masalah yang perlu diketahui faktor-faktor yang mempengaruhi keputusan rumah tangga melibatkan anak dalam kegiatan ekonomi.

Fenomena anak-anak yang bekerja terjadi di berbagai belahan dunia, dan tidak hanya terjadi di negara berkembang seperti anggapan yang dipahami khalayak luas. Pada tahun 2020, diperkirakan terdapat 266 ribu anak usia 16-17 tahun yang bekerja di Amerika Serikat, 216 ribu di antaranya bekerja lebih dari 35 jam per minggu (US Bureau for Labor Statistics, 2020). Data Badan Pusat Statistik (BPS) menunjukkan bahwa pekerja anak di Indonesia tahun 2019 sekitar 1,6 juta orang. Pekerja anak tersebut tersebar di seluruh Indonesia. Jawa merupakan wilayah dengan pekerja anak tertinggi yang diperkirakan mencapai 565 ribu orang dan Maluku dengan kasus terendah. Sebagai daerah tujuan wisata, di Bali masih terdapat sekitar 24 ribu orang pekerja anak atau sebesar 1,5 persen dari total pekerja anak di Indonesia (Syaifudin \& Andini, 2020). Masalah keterlibatan anak dalam dunia kerja di Bali sangat menarik untuk dikaji. Dengan mengkaji mengenai akar masalah penyebab pekerja anak ini akan sangat berguna untuk mendukung target pengentasan pekerja anak pada tahun 2022, khususnya di Provinsi Bali.

Berbagai penelitian telah dilakukan untuk mengurai penyebab fenomena pekerja anak. Webbink et al (2013) mengembangkan kerangka teori untuk menjelaskan keterlibatan anak-anak dalam dunia kerja di negara berkembang. Kerangka teori tersebut dibagi ke dalam tiga level (nasional, wilayah, dan rumah tangga) dan tiga kelompok variabel penjelas (sumberdaya, struktur, dan budaya). Sekitar delapan persen anak usia 10-15 tahun di China bekerja dan kondisi tersebut berkaitan erat dengan angka putus sekolah (Tang et al., 2018). Kemiskinan dan norma sosial merupakan alasan anak-anak bekerja di pertambangan cobalt di Kongo (Faber et al., 2017). Admaw \& Ghosal (2018) menemukan bahwa utang orang tua merupakan salah satu penyebab anak-anak bekerja.

Keputusan rumah tangga mengirimkan anak-anak masuk ke dalam bursa kerja dipengaruhi berbagai hal yang sangat kompleks. Faktor-faktor tersebut adalah karakteristik rumah tangga, sosial, dan ekonomi. Karakteristik rumah tangga yang berpengaruh adalah jenis kelamin anak ((Fithriani (2012), Webbink et al (2013), dan Fahlevi (2020)), jenis kelamin kepala rumah tangga (Ardana et al., 2016), umur anak (Admaw \& Ghosal, 2018), umur kepala rumah tangga (Adeoye et al., 2017), dan daerah tempat tinggal (Webbink et al (2013) 
dan Darmika \& Usman (2021)). Kondisi sosial dapat dilihat dari status perkawinan kepala rumah tangga (Darmika \& Usman, 2021), disabilitas kepala rumah tangga (Lal, 2019), jumlah tanggungan dalam rumah tangga (Uppun, 2016) dan pendidikan kepala rumah tangga ((Suryati \& Suryaningsih (2015), (Ariyanti (2016), dan Thiong'o (2020). Sedangkan dari aspek ekonomi dapat dilihat status pekerjaan kepala rumah tangga (Darmika \& Usman, 2021), utang rumah tangga (Admaw \& Ghosal, 2018), status kemiskinan (Lal, 2019), dan jam kerja kepala rumah tangga (Rusmusi \& Maghfira, 2018).

Keterlibatan anak-anak dalam dunia kerja sangat ditentukan oleh kepala rumah tangga, meskipun dalam beberapa kasus melibatkan anggota keluarga yang lain (Webbink et al., 2013). Laporan dari Kongo menunjukkan bahwa 25 persen anak-anak bekerja atas kemauannya sendiri dan persentase tersebut menjadi lebih tinggi pada anak-anak yang bekerja di sektor pertambangan, kondisi ini mungkin terjadi karena secara umum usia anak-anak tersebut lebih tua (Faber et al., 2017).

Kajian mengenai pekerja anak tidak hanya dilakukan dari sudut pandang sosial dan ekonomi, tapi juga dari perspektif lain. Penelitian dari sisi psikologi misalnya dilakukan oleh Rizkianto et al (2015), dari perspektif agama dilakukan oleh Azizah (2015), dan dari aspek hukum dilakukan oleh Asmorowati (2008), Endrawati (2011), Piri (2013), Subekti (2018), Ambara et al (2018), Subekti (2018), Yulianingsih \& Purwanto (2019), dan Izziyana (2019). Bahkan penelitian dari aspek kesehatan seperti yang dikaji oleh Yanti (2014) menemukan kasus pekerja anak yang berprofesi sebagai tukang suun di pasar Badung Denpasar mengalami keluhan kesehatan berupa sakit leher dan pusing. Handy \& Soedjatmiko (2016) juga mengungkapkan bahwa terjadi gangguan kesehatan pada anak jalanan di Jakarta.

Pekerja anak yang bekerja pada lingkungan berbahaya, mengganggu tumbuh kembang, dan kesehatannya merupakan target untuk dieliminasi, sedangkan keterlibatan anak-anak pada pekerjaan yang tidak mengganggu kesehatan, perkembangan, dan sekolahnya merupakan sesuatu yang positif dan berguna dalam kehidupannya di masa depan (ILO, 2004). Faktor budaya yang menganggap anak yang bekerja sebagai bentuk pengabdian kepada orang tua dan merupakan proses sosialisasi menuju kedewasaan diungkap oleh Endrawati (2011). Pendapat senada juga diungkapkan oleh Bachman (2000) yang menyatakan bahwa pada komunitas tertentu terdapat anggapan bahwa bekerja sangat bermanfaat bagi anak-anak sepanjang anakanak tersebut merasa belajar dari pekerjaannya.

Berbagai Undang-Undang (UU) maupun peraturan telah dikeluarkan untuk melindungi hak-hak anak di Indonesia. UU No. 23 tahun 2002 tentang perlindungan anak telah dilakukan perubahan sebanyak dua kali melalui UU No. 35 tahun 2014 dan UU No. 17 tahun 2016. Selain UU, pemerintah juga menerbitkan Peraturan Menteri Pemberdayaan Perempuan dan Perlindungan Anak No. 7 tahun 2019 tentang pedoman perlindungan anak dari radikalisme dan tindak pidana terorisme. Bentuk-bentuk pekerjaan terburuk untuk anak (BPTA) ditemukan pada jenis pekerjaan di bidang prostitusi, pertambangan, perikanan laut dalam, perdagangan narkoba, dan pekerjaan sektor rumah tangga. Pemerintah Indonesia berkomitmen untuk menanggulangi pekerja anak, khususnya BPTA, komitmen tersebut terlihat pada target bebas dari pekerja pada tahun 2022 anak dengan berbagai kebijakan program perlindungan sosial (Kemnaker, 2014).

Berdasarkan penelitian-penelitian di atas, dapat disimpulkan bahwa variabelvariabel yang berpengaruh terhadap keputusan rumah tangga melibatkan anaknya dalam kegiatan ekonomi adalah tempat tinggal, jenis kelamin anak, jenis kelamin kepala rumah tangga, umur kepala rumah tangga, umur anak, status disabilitas

Jurnal IImu Sosial dan Humaniora | 311 
kepala rumah tangga, pengeluaran per kapita rumah tangga, status pendidikan kepala rumah tangga, status bekerja kepala rumah tangga, jam kerja kepala rumah tangga, jumlah anggota rumah tangga, status perkawinan kepala rumah tangga, kredit yang diterima, dan bantuan pangan non tunai yang diterima rumah tangga baik secara parsial maupun simultan. Tujuan utama penelitian ini adalah mengkaji seberapa besar pengaruh variabel-variabel hipotesis tersebut dalam kaitannya dengan munculnya pekerja anak. Penelitian ini akan fokus pada karakteristik anak, rumah tangga, dan kepala rumah tangga yang menyebabkan munculnya pekerja anak agar memudahkan pemerintah, khususnya di Provinsi Bali dalam membuat kebijakan untuk menanggulangi fenomena pekerja anak.

Beberapa keterbatasan dalam penelitian ini adalah data yang digunakan hanya dapat mengukur pekerja anak yang tinggal dalam rumah tangga biasa. Penelitian ini tidak dapat mengukur pekerja anak yang berstatus gelandangan maupun yang berusia di bawah 10 tahun.

\section{METODE}

Dalam penelitian ini, karena keterbatasan data, pekerja anak yang dimaksud merupakan penduduk berusia 1017 tahun yang bekerja. Data yang digunakan bersumber dari Survei Sosial Ekonomi Nasional (Susenas) 2020. Susenas hanya menanyakan aktivitas bekerja kepada mereka yang berusia 10 tahun ke atas. Survei tersebut dilakukan pada bulan Maret 2020, dengan demikian, maka walaupun survei itu dilakukan tepat pada saat pertama kali kasus Covid-19 ditemukan di Indonesia, namun diasumsikan bahwa data yang diperoleh merupakan data kondisi pekerja anak yang belum dipengaruhi oleh dampak Covid-19.

Metode analisis yang digunakan dalam penelitian berupa analisis deskriptif dan inferensia. Analisis deskriptif dilakukan untuk melihat gambaran pekerja anak di Bali tahun
2020, yang ditampilkan dalam bentuk tabel dan grafik. Analisis statistik inferensial yang digunakan adalah regresi logistik biner. Regresi logistik biner merupakan suatu metode analisis yang menjelaskan pengaruh sekelompok variabel bebas terhadap variabel terikat yang berbentuk biner atau dikotomi. Variabel bebas dapat berupa data kualitatif berskala nominal atau ordinal maupun data kuantitatif berskala interval atau rasio. Model yang dibentuk dalam regresi logistik biner adalah sebagai berikut (Agresti, 2013):

$\operatorname{Logit}[\pi(x)]=\alpha+\beta_{1} x_{1}+\cdots+\beta_{p} x_{p}$

Rumus alternatif yang dapat menduga nilai $\pi(x)$ secara langsung adalah sebagai berikut:

$\pi(x)=\frac{\exp \left(\alpha+\beta_{1} x_{1}+\cdots+\beta_{p} x_{p}\right)}{1+\exp \left(\alpha+\beta_{1} x_{1}+\cdots+\beta_{p} x_{p}\right)}$

Keterangan:

$\pi(x)=$ peluang kejadian sukses

$\beta_{p} \quad=$ nilai parameter ke-p dengan $\mathrm{p}=1,2, \ldots \mathrm{p}$

$x_{p} \quad=$ variabel penjelas ke-p dengan $p=1,2, \ldots p$

\section{HASIL DAN PEMBAHASAN}

Pekerja anak di Bali pada tahun 2020 diperkirakan mencapai mencapai 24 ribu orang. Berdasarkan jenis kelamin, 70 persen pekerja anak tersebut adalah perempuan. Kondisi tersebut diduga berkaitan dengan kemampuan wanita Bali dalam menjalankan perannya di dalam keluarga, baik secara ekonomi dan budaya secara seimbang (Komalasari, 2017). Fakta bahwa pekerja anak di Bali didominasi oleh perempuan, bertentangan dengan temuan Purwoko (2013) yang menyatakan bahwa pekerja anak didominasi oleh laki-laki.

Jurnal IImu Sosial dan Humaniora | 312 


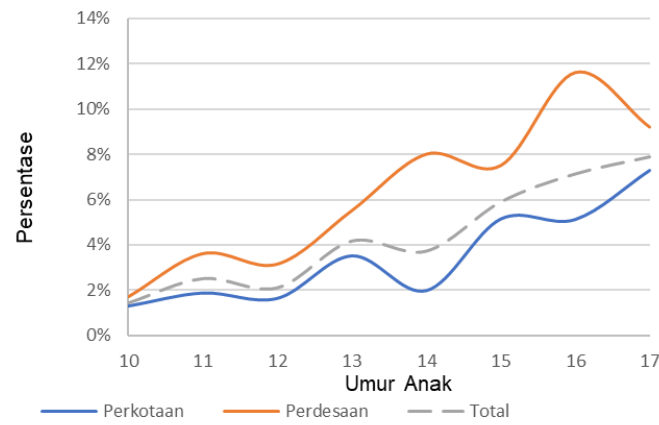

Gambar 1. Persentase Pekerja Anak Menurut Klasifikasi Daerah dan Umur di Provinsi Bali Tahun 2020

Sumber: Susenas tahun 2020, diolah

Gambar 1 menunjukkan persentase pekerja anak di perdesaan lebih tinggi daripada di perkotaan. Persentasenya tampak meningkat seiring dengan bertambahnya umur anak. Tang et al (2018) mengungkapkan bahwa anak-anak yang tinggal di perdesaan lebih cenderung bekerja. Tingginya persentase anak-anak usia 15-17 tahun yang bekerja juga diungkap oleh Faber et al (2017).

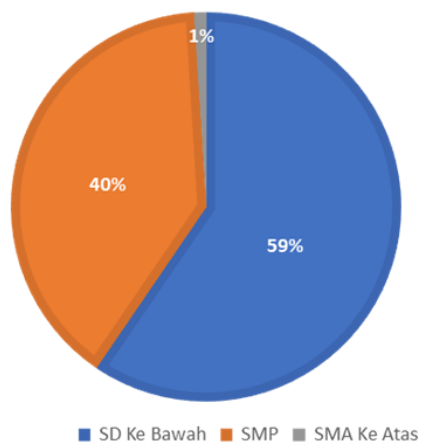

Gambar 2. Persentase Pekerja Anak Berdasarkan Tingkat Pendidikan Kepala Rumah Tangga di Provinsi Bali Tahun 2020

Sumber: Susenas tahun 2020, diolah

Munculnya pekerja anak berkaitan dengan tingkat pendidikan kepala rumah tangga, kondisi tersebut terlihat pada Gambar 2. Persentase pekerja anak dimana pendidikan kepala rumah tangganya SD ke bawah menempati posisi pertama, sedangkan pekerja anak dengan pendidikan kepala rumah tangga SMA ke atas menempati porsi paling kecil. Kondisi tersebut menunjukkan bahwa semakin tinggi pedidikan kepala rumah tangga maka semakin sedikit melibatkan anak dalam kegiatan ekonomi. Temuan tersebut sejalan dengan Uppun (2016) yang menyatakan bahwa kemunculan pekerja anak berhubungan dengan tingkat pendidikan kepala rumah tangga.

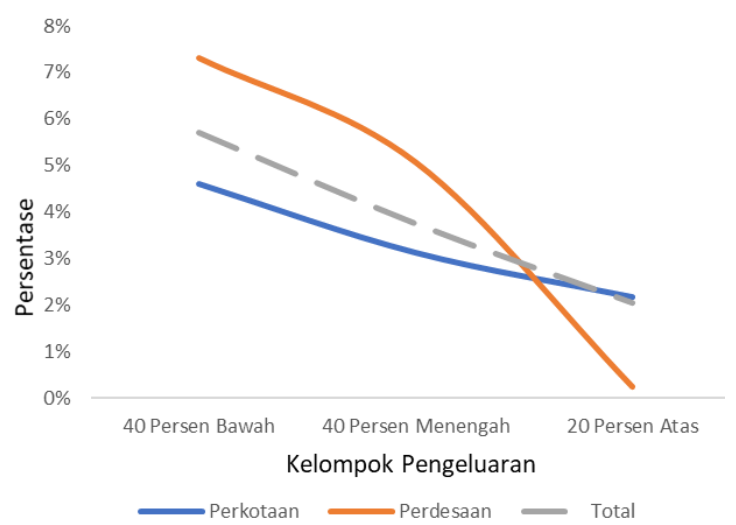

Gambar 3. Persentase Pekerja Anak Menurut Kelompok Pengeluaran dan Klasifikasi Daerah di Provinsi Bali 2020

Sumber: Susenas tahun 2020, diolah

Karakteristik pekerja anak dilihat dari kelompok pengeluarannya ditunjukkan oleh Gambar 3. Gambar tersebut mengonfirmasi asumsi bahwa kemunculan pekerja anak berkaitan erat dengan tingkat kemiskinan. Persentase pekerja anak pada kelompok pengeluaran 40 persen terbawah jauh lebih tinggi daripada pekerja anak pada kelompok pengeluaran 20 persen teratas. Kondisi tersebut terjadi baik di daerah perdesaan maupun perkotaan. Temuan ini didukung oleh Faber et al (2017) yang mengungkapkan bahwa kemiskinan merupakan salah satu faktor yang menyebabkan anak-anak terlibat dalam kegiatan ekonomi.

Jurnal IImu Sosial dan Humaniora | 313 


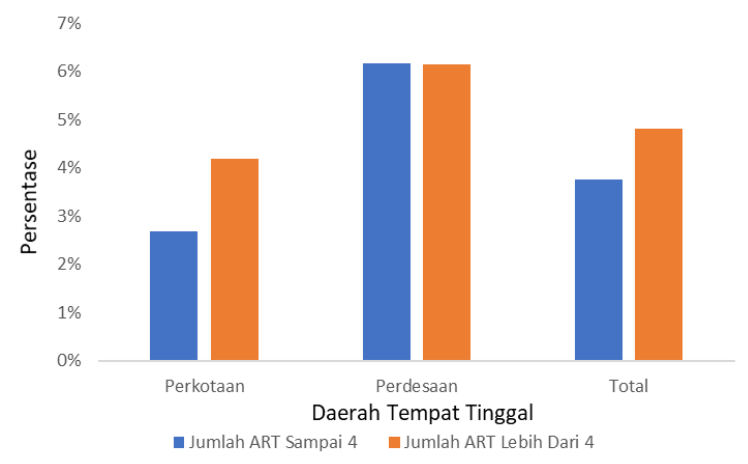

Gambar 4. Persentase Pekerja Anak Menurut Jumlah Anggota Rumah Tangga dan Daerah Tempat Tinggal di Provinsi Bali 2020

Sumber: Susenas tahun 2020, diolah

Jumlah anggota rumah tangga atau jumlah tanggungan juga diduga menjadi penyebab munculnya pekerja anak. Dalam penelitian ini ditemukan bahwa pada daerah perkotaan, rumah tangga dengan anggota lebih dari empat memiliki persentase pekerja anak lebih tinggi dibandingkan dengan rumah tangga yang anggotanya empat ke bawah, sebagaimana ditunjukkan oleh Gambar 4. Namun demikian kondisi itu hanya berlaku di daerah perkotaan. Adapun untuk daerah perdesaan, tidak menunjukkan adanya perbedaan persentase pekerja anak antara rumah tangga dengan jumlah anggota empat ke bawah maupun yang lebih dari empat. Temuan tersebut didukung oleh Uppun (2016) yang menunjukkan bahwa semakin banyak tanggungan dalam sebuah keluarga maka akan semakin besar peluang anakanak dilibatkan dalam kegiatan ekonomi dan Admaw \& Ghosal (2018) yang mengungkap bahwa banyaknya anggota keluarga berpengaruh positif terhadap keputusan rumah tangga melibatkan anak dalam dunia kerja.

Sebagaimana dijelaskan sebelumnya, analisis inferensia yang digunakan dalam penelitian ini adalah regresi logistik. Untuk itu, pengujian secara parsial maupun simultan dilakukan untuk mengetahui signifikansi parameter. Uji likelihood ratio dilakukan untuk mengetahui pengaruh variabel penjelas terhadap variabel respon secara bersama-sama (simultan) dalam model regresi logistik biner.

Tabel 1. Hasil Pengujian Secara Simultan

\begin{tabular}{ccc}
\hline Chi-square & Derajat Bebas & P-value \\
\hline 123,082 & 16 & $0,00^{*}$ \\
\hline
\end{tabular}

*: signifikan pada $\alpha=0,05$

Hasil pengujian secara simultan yang ditampilkan pada Tabel 1 menunjukkan bahwa nilai chi square hitung sebesar 123,082 > 26,296 (chi square tabel) dan Pvalue $<0,05$, sehingga nilai itu menghasilkan keputusan menolak $\mathrm{H}_{0}$. Hal ini mengindikasikan adanya variabel penjelas, setidaknya satu variabel, yang berpengaruh terhadap munculnya pekerja anak di Bali tahun 2020.

Hasil uji pada Tabel 2 menunjukkan bahwa model yang digunakan sudah tepat. Model dikatakan tepat jika tidak ada perbedaan signifikan antara model dengan nilai observasinya. Hal ini ditunjukkan oleh nilai chi square hitung sebesar 6,158 < 15,507 (chi square tabel) dan nilai P-value > 0,05 .

Berdasarkan kedua hasil uji tersebut, maka pengujian secara parsial dapat dilanjutkan. Pengujian parsial dilakukan untuk mendapatkan informasi variabel penjelas yang berpengaruh signifikan terhadap variabel respon. Pengujian dilakukan dengan metode Wald dengan hasil uji sebagaimana ditampilkan pada Tabel 3. Hasil pengujian secara parsial menyimpulkan bahwa variabel klasifikasi tempat tinggal, jenis kelamin anak, umur anak, umur kepala rumah tangga, status perkawinan kepala rumah tangga, status disabilitas kepala rumah tangga, pendidikan kepala rumah tangga, dan bantuan pangan yang diterima rumah tangga berpengaruh signifikan terhadap munculnya pekerja anak di Bali.

Jurnal IImu Sosial dan Humaniora| 314 
Tabel 2. Hasil Uji Hosmer And Lemeshow

\begin{tabular}{ccc}
\hline Chi-square & $\begin{array}{c}\text { Derajat } \\
\text { Bebas }\end{array}$ & P-value \\
\hline 6,158 & 8 & $0,630^{*}$ \\
\hline
\end{tabular}

${ }^{*}$ : signifikan pada $\alpha=0,05$

Tabel 3. Hasil Uji Wald

\begin{tabular}{|c|c|c|c|c|c|c|}
\hline Nama Variabel & Kategori & Simbol & $\hat{\beta}$ & S.E & P-value & $\operatorname{Exp}(\hat{\beta})$ \\
\hline Konstanta & & & $-3,983$ & 1,660 & 0,016 & 0,019 \\
\hline Klasifikasi & $0=$ Perdesaan $\left.{ }^{*}\right)$ & & & & & \\
\hline \multirow{3}{*}{$\begin{array}{l}\text { Daerah } \\
\text { Jenis Kelamin } \\
\text { Anak }\end{array}$} & 1 = Perkotaan & $x_{1}$ & 0,435 & 0,180 & $0,016^{*}$ & 1,545 \\
\hline & $0=$ Perempuan ${ }^{*}$ ) & & & & & \\
\hline & 1 = Laki-laki & $\mathrm{x}_{2}$ & $-0,732$ & 0,185 & $0,000^{*}$ & 0,481 \\
\hline Usia Anak & Rasio & $x_{3}$ & 0,331 & 0,064 & $0,000^{*}$ & 1,392 \\
\hline Usia KRT & Rasio & $\mathrm{X}_{4}$ & $-0,025$ & 0,012 & $0,031^{*}$ & 0,975 \\
\hline Status & $0=$ Tidak Kawin $/$ Cerai ${ }^{*}$ ) & & & & & \\
\hline Perkawinan KRT & $1=$ Kawin & $x_{5}$ & $-0,812$ & 0,400 & $0,043^{*}$ & 0,444 \\
\hline $\begin{array}{l}\text { Jam Kerja KRT } \\
\text { Jenis Kelamin }\end{array}$ & Rasio & $X_{6}$ & 0,007 & 0,006 & 0,239 & 1,007 \\
\hline KRT & $0=$ Perempuan $*$ ) & & & & & \\
\hline Disabilitas KRT & $\begin{array}{l}1=\text { Laki-laki } \\
0=\text { Tidak Disabilitas *) }\end{array}$ & $\mathrm{X}_{7}$ & $-0,177$ & 0,447 & 0,692 & 0,838 \\
\hline & $1=$ Disabilitas & $X_{8}$ & 0,813 & 0,320 & $0,011^{*}$ & 2,254 \\
\hline \multirow[t]{3}{*}{ Pendidikan KRT } & $0=$ SD Ke Bawah *) & & & & $0,002^{*}$ & \\
\hline & $1=\mathrm{SMP}$ & $X_{91}$ & $-2,635$ & 0,974 & $0,007^{*}$ & 0,072 \\
\hline & $\begin{array}{l}2=\text { SMA Ke Atas } \\
0=\text { Tidak Bekerja } *\end{array}$ & $\mathrm{X}_{92}$ & $-3,081$ & 0,956 & $0,001^{*}$ & 0,046 \\
\hline KRT & 1 = Bekerja & $X_{10}$ & 0,369 & 0,619 & 0,551 & 1,446 \\
\hline \multirow{2}{*}{\multicolumn{7}{|c|}{$\begin{array}{l}\text { Ruta } \\
\text { Menerima }\end{array}$}} \\
\hline & & & & & & \\
\hline Bantuan Pangan & $0=$ Tidak Menerima & & & & & \\
\hline Tunai & $\begin{array}{l}\text { Bantuan Pangan *) } \\
1=\text { Menerima Bantuan } \\
\text { Pangan }\end{array}$ & $x_{11}$ & 0,737 & 0,203 & $0,000^{*}$ & 2,089 \\
\hline $\begin{array}{l}\text { Ruta Menerima } \\
\text { KUR }\end{array}$ & $\begin{array}{l}0=\text { Tidak Menerima KUR } \\
\left.{ }^{*}\right)\end{array}$ & & & & & \\
\hline Kelompok & $\begin{array}{l}1=\text { Menerima KUR } \\
0=40 \text { Persen Terbawah }{ }^{*} \text { ) }\end{array}$ & $\mathrm{x}_{12}$ & $-0,307$ & 0,269 & $\begin{array}{l}0,254 \\
0,403\end{array}$ & 0,736 \\
\hline Pengeluaran Per & $1=40$ Persen Menengah & $x_{131}$ & 0,499 & 0,374 & 0,183 & 1,647 \\
\hline $\begin{array}{l}\text { Kapita Rumah } \\
\text { Tangga }\end{array}$ & $2=20$ Persen Atas & $\mathrm{X}_{132}$ & 0,390 & 0,372 & 0,295 & 1,477 \\
\hline Jumlah ART & Rasio & $x_{14}$ & 0,024 & 0,186 & 0,896 & 1,025 \\
\hline
\end{tabular}

Sumber: Susenas tahun 2020, diolah

Keterangan: $\left.{ }^{*}\right)=$ kategori referensi ${ }^{*}=$ signifikan pada $\alpha=5 \%$

KUR: Kredit Usaha Rakyat; KRT: Kepala Rumah Tangga; ART: Anggota Rumah Tangga

Berdasarkan hasil uji pada Tabel 3 ,

maka persamaan regresi logistik yang

terbentuk adalah sebagai berikut:
$\operatorname{Logit}[\pi(x)]=-3,983+0,435 x_{1}{ }^{*}-0,732 x_{2}{ }^{*}+$ $0,331 x_{3}{ }^{*}-0,025 x^{*}-0,812 x_{5}{ }^{*}+0,007 x_{6}-$ $0,177 x_{7}+0,813 x_{8}{ }^{*}-2,635 x_{91}{ }^{*}-3,081 x_{92}{ }^{*}+$ 
$0,369 x_{10}+0,737 x_{11}{ }^{*}-0,307 x_{12}+0,499 x_{131}+$ $0,390 x_{132}+0,024 x_{14}$

Hasil uji Wald juga menghasilkan temuan bahwa jam kerja kepala rumah tangga tidak berpengaruh terhadap munculnya pekerja anak. Temuan ini sejalan dengan Darmika \& Usman (2021) yang menunjukkan bahwa jam kerja kepala rumah tangga tidak berpengaruh secara signifikan terhadap munculnya pekerja anak.

Tabel 3 juga menjelaskan bahwa jenis kelamin kepala rumah tangga tidak memberikan pengaruh signifikan terhadap keputusan rumah tangga mengirimkan anak-anaknya ke bursa kerja. Temuan ini sejalan dengan apa yang diungkapkan oleh Tang et al (2018), bahwa kemunculan pekerja anak tidak dipengaruhi oleh jenis kelamin dan pendidikan kepala rumah tangga.

Pada taraf signifikansi 5 persen, ditemukan fakta bahwa status bekerja kepala rumah tangga tidak berpengaruh secara signifikan terhadap keputusan mengirimkan anak ke bursa kerja. Temuan ini berbeda dengan Uppun (2016) yang mengungkapkan bahwa jenis pekerjaan kepala keluarga berpengaruh terhadap keputusan melibatkan anak-anak dalam kegiatan ekonomi.

Dugaan bahwa utang rumah tangga berpengaruh terhadap kemunculan pekerja anak tidak didukung oleh hasil uji Wald yang ditunjukkan oleh hasil uji yang tidak signifikan antara kemunculan pekerja anak dengan penerimaan KUR rumah tangga. Temuan ini tidak sejalan dengan Admaw \& Ghosal (2018) yang mengungkap bahwa jam kerja pekerja anak dipengaruhi oleh utang kepala rumah tangga.

Jumlah anggota rumah tangga tidak berpengaruh secara signifikan terhadap munculnya pekerja anak di Bali, kondisi ini ditunjukkan pada Tabel 3. Temuan ini berbeda dengan Uppun (2016) yang menggambarkan bahwa jumlah tanggungan keluarga berpengaruh signifikan terhadap munculnya pekerja anak.

Temuan dalam penelitian ini menunjukkan bahwa rumah tangga penerima bantuan pangan non tunai memiliki kecenderungan memunculkan pekerja anak 2,1 kali dibandingkan dengan rumah tangga yang tidak menerima bantuan pangan non tunai. Temuan tersebut sejalan dengan berbagai temuan yang menyatakan bahwa kemiskinan merupakan faktor pemicu munculnya pekerja anak (Darmika \& Usman (2021), Thiong'o (2020) dan Saleh et al (2019)). Namun demikian, dalam studi ini juga ditemukan bahwa penggunaan variabel kemiskinan absolut yang diukur dari kelompok pengeluaran per kapita rumah tangga menunjukkan bahwa kemiskinan absolut tidak berpengaruh signifikan terhadap keterlibatan anak secara ekonomi. Temuan tersebut sejalan dengan Uppun (2016) yang menyatakan bahwa kemiskinan absolut bukan merupakan satu-satunya faktor penyebab munculnya pekerja anak.

Uji Wald menunjukkan bahwa klasifikasi daerah tempat tinggal berpengaruh secara signifikan terhadap keterlibatan anak secara ekonomi. Nilai rasio kecenderungan sebesar 1,545 menunjukkan bahwa anak-anak yang tinggal di daerah perkotaan memiliki peluang 1,5 kali lipat untuk bekerja dibandingkan dengan anak-anak yang tinggal di perdesaan. Temuan tersebut sejalan dengan Wardana \& Sari (2020) yang menemukan bahwa pekerja anak di wilayah perkotaan memiliki kecenderungan lebih tinggi mengalami eksploitasi dibandingkan dengan pekerja anak di perdesaan. Webbink et al (2013) menyatakan bahwa pada daerah perkotaan yang belum maju, memiliki kecenderungan memunculkan pekerja anak.

Jenis kelamin anak berpengaruh secara signifikan terhadap keterlibatannya dalam aktivitas ekonomi. Anak laki-laki di Bali memiliki kecenderungan bekerja sebesar 0,48 dibandingkan dengan anak 
perempuan, dengan kata lain anak perempuan memiliki peluang kerja 2 kali lipat dibandingkan anak laki-laki. Fakta tersebut terlihat dari nilai $\operatorname{Exp}(\hat{\beta})$ pada Tabel 3 yang sebesar 0,481 . Fakta tersebut berkaitan dengan kemampuan wanita Bali dalam menjalankan peran secara seimbang dalam kegiatan ekonomi maupun budaya (Komalasari, 2017). Temuan tersebut sejalan dengan Fahlevi (2020) yang menyebutkan bahwa jenis kelamin anak merupakan salah satu faktor penentu terlibatnya anak-anak dalam pekerjaan.

Tabel 3 menunjukkan bahwa dalam pengujian secara parsial pada taraf signifikansi 5 persen, baik usia anak maupun usia kepala rumah tangga berpengaruh secara signifikan terhadap aktivitas ekonomi anak. Perbedaan antara kedua temuan tersebut bahwa pada variabel usia anak, semakin bertambah usia anak maka kecenderungannya bekerja menjadi lebih besar, hal tersebut terlihat pada nilai $\operatorname{Exp}(\hat{\beta})$ sebesar 1,392. Temuan tersebut sesuai dengan Faber et al (2017) yang mengungkapkan bahwa pekerja anak yang bekerja pada pertambangan cobalt secara umum lebih tua. Sedangkan pada variabel umur orang tua terlihat bahwa semakin bertambah umur orang tua semakin kecil peluang anak-anak bekerja. Kondisi tersebut berbeda dengan temuan Uppun (2016) yang menyatakan bahwa semakin tua usia kepala keluarga maka semakin besar peluang anak bekerja.

Temuan lain yang dapat diungkap dalam penelitian ini adalah bahwa rumah tangga yang kepala rumah tangganya berstatus kawin berpeluang lebih kecil mengirimkan anak-anaknya ke dunia kerja dibandingkan dengan rumah tangga yang kepala rumah tangganya belum kawin ataupun sudah bercerai. Temuan tersebut bersesuaian dengan Darmika \& Usman (2021) yang mengungkapkan bahwa peluang anak yang kepala rumah tangganya single/cerai berpeluang lebih besar memiliki pekerja anak.

Uji Wald juga menggambarkan bahwa status disabilitas kepala rumah tangga berpengaruh signifikan terhadap munculnya pekerja anak, rumah tangga yang kepala rumah tangganya disable berpeluang 2 kali lipat mengirimkan anaknya ke dunia kerja dibandingkan dengan rumah tangga yang kepala rumah tangganya tidak mengalami disabilitas. Temuan tersebut sejalan dengan Lal (2019) yang menunjukkan bahwa pada rumah tangga yang terdapat orang tua yang sakit, kecanduan alkohol, dan menderita disabilitas cenderung mengirimkan anakanak untuk bekerja untuk mendapatkan penghasilan.

Status pendidikan kepala rumah tangga juga merupakan variabel yang secara signifikan berpengaruh terhadap keputusan rumah tangga mempekerjakan anaknya. Rumah tangga yang kepala rumah tangganya berpendidikan SD ke bawah berpeluang paling besar mengirimkan anaknya ke dunia kerja dibandingkan dengan rumah tangga yang kepala rumah tangganya berpendidikan SMP maupun SMA ke atas. Peluang anak yang kepala rumah tangganya berpendidikan SMA ke atas hanya 0,05 kali dibandingkan dengan anak yang kepala rumah tangganya berpendidikan SD ke bawah. Temuan ini sejalan dengan Darmika \& Usman (2021) dan Wardana \& Sari (2020) yang menunjukkan bahwa semakin tinggi pendidikan kepala rumah tangga maka semakin kecil peluang anak-anaknya bekerja.

Berdasarkan temuan-temuan dalam penelitian ini, terlihat bahwa karakteristik sosial dan ekonomi rumah tangga berpengaruh terhadap keputusan rumah tangga melibatkan anak-anaknya dalam kegiatan ekonomi. Langkah antisipasi terhadap munculnya pekerja anak di Bali dapat dilakukan dari tingkat rumah tangga, penguatan ekonomi dan peningkatan pemahaman mengenai dampak negatif 
yang muncul dari mempekerjakan anak merupakan suatu keharusan.

\section{SIMPULAN DAN SARAN}

Pada tahun 2020, pekerja anak di Bali mencapai 24 ribu orang, dan lebih dari dua pertiga adalah perempuan. Hal ini dapat terjadi karena budaya di Bali bahwa selain menjalankan fungsi keluarga, perempuan juga menjalankan fungsi ekonomi. Penelitian juga menemukan bahwa persentase anak-anak yang bekerja di perdesaan lebih tinggi daripada anak-anak yang bekerja di perkotaan. Dilihat dari tingkat pendidikan kepala rumah tangganya, persentase pekerja anak yang kepala rumah tangganya berpendidikan SD jauh lebih tinggi daripada pekerja anak yang kepala rumah tangganya berpendidikan SMA ke atas. Kondisi yang hampir serupa terjadi pada pekerja anak berdasarkan kelompok pengeluaran rumah tangga, anak-anak yang rata-rata pengeluaran per kapita rumah tangganya berada pada kelompok 40 persen pengeluaran terbawah persentase pekerja anaknya lebih tinggi daripada anakanak yang rata-rata pengeluaran rumah tangganya berada pada kelompok 20 persen teratas. Persentase pekerja anak yang jumlah anggota rumah tangganya lebih dari empat lebih tinggi daripada pekerja anak yang jumlah anggota rumah tangganya empat orang atau kurang.

Penelitian ini juga menemukan bahwa klasifikasi daerah tempat tinggal, jenis kelamin anak, usia anak, usia kepala rumah tangga, status perkawinan kepala rumah tangga, status disabilitas kepala rumah tangga, tingkat pendidikan kepala rumah tangga, dan penerimaan bantuan pangan tunai rumah tangga berpengaruh signifikan terhadap munculnya pekerja anak. Anakanak yang tinggal di perkotaan, memiliki kepala rumah tangga menderita disabilitas, status perkawinan kepala rumah tangga belum kawin/cerai, dan pendidikan kepala rumah tangga SD berpeluang lebih besar menjadi pekerja.
Penelitian lebih lanjut yang menarik untuk dilakukan adalah mengenai dampak pandemi COVID-19, khususnya sektor pariwisata di Bali yang mengalami guncangan keras dan mengakibatkan naiknya angka pengangguran dan kemiskinan terhadap kemunculan pekerja anak. Selain itu, pengukuran pekerja anak yang bekerja pada lingkungan berbahaya serta anak jalanan juga perlu diteliti untuk mendapatkan gambaran mengenai kondisi eksploitasi pekerja anak.

\section{DAFTAR PUSTAKA}

Adeoye, S. O., Agbonlahor, M. U., Ashaolu, O. F., \& Ugalahi, U. B. (2017). Analysis of child labour dimensions and causes in rural farm households of Ogun state, Nigeria. African Journal of Food, Agriculture, Nutrition and Development, 17(3). https://doi.org/10.18697/ajfand.79.160 30

Admaw, T., \& Ghosal, S. (2018). SocioEconomic Determinants Of Child Labor Exploitation: The Case Study Of Jimma Town, Ethiopia. International Journal of Economics \& Finance Research \& Applications, 2(1), 12-23. http://management.eurekajournals.co m/index.php/lJEFRA/article/view/198

Agresti, A. (2013). Categorical Data Analysis (D. J. Balding, N. A. C. Cressie, G. M. Fitzmaurice, H. Goldstein, I. M. Johnstone, G. Molenberghs, \& D. W. Scott (eds.); Third Edit). Willey Interscience.

Ambara, M. A., Udiana, I. M., \& Mudana, I. N. (2013). Perlindungan hukum pekerja anak pada usaha asongan di sayan delodan mengwi badung. Kerta Semaya: Journal IImu Hukum, 01(Vol. 01, No. 10, Oktober 2013), 1-16. https://ojs.unud.ac.id/index.php/kertha semaya/article/view/42081

Ardana, I. M. J., Arjana, I. G. B., \& Ramang, R. (2016). Pengaruh Lingkungan Tempat Tinggal Dan Karakteristik Jurnal IImu Sosial dan Humaniora| 318 
Rumah Tangga Terhadap Munculnya Pekerja Anak Di NTT (Analisis Data Susenas Dan Potensi Desa 2011). Bumi Lestari Journal of Environment, 16(2), 100. https://doi.org/10.24843/blje.2016.v16. i02.p03

Ariyanti, I. (2016). Studi Kasus Pekerja Anak Di Kecamatan Sematang Borang Kota Palembang. Jurnal IImiah STIE MDP, 5(2), 80-93.

Asmorowati, S. (2008). Efektivitas Kebijakan Perlindungan Anak (Child Labour) dengan Fokus Anak Jalanan di Surabaya. Jurnal Penelitian Dinas Sosial, 7(1), 31-44. http://www.eskom.co.za/CustomerCar e/TariffsAndCharges/Documents/RSA Distribution Tariff Code Vers 6.pdf\%0Ahttp://www.nersa.org.za/

Azizah, T. (2015). Tinjauan Hukum Islam Terhadap Pekerja Anak Di Bawah Umur (Studi Analisis UU RI No. 13 Tahun 2003 Tentang Ketenagakerjaan Perspektif Mashlahah). In Universitas Islam Negeri Walisongo Semarang.

Bachman, S. L. (2000). Journal of International Affairs Editorial Board A New Economics of Child Labor: Searching for Answers Behind the Headlines All use subject to http://about.jstor.org/terms A New Economics of Child Labor: Searching for Answers Behind the Headlines. Journal of International Affairs, 53(2), 545-572.

Badan Pusat Statistik. (2010). Pekerja Anak DI Indonesia 2009. https://www.ilo.org/wcmsp5/groups/pu blic/@asia/@ro-bangkok/@ilojakarta/documents/presentation/wcms 346599.pdf

Darmika, W. D. B., \& Usman, H. (2021). Pengaruh Karakteristik Kepala Rumah Tangga Dan Rumah Tangga Terhadap Munculnya Pekerja Anak Di Indonesia Tahun 2018. Seminar Nasional Official Statistics, 2020(1), 462-471. https://doi.org/10.34123/semnasoffstat .v2020i1.399

Endrawati, N. (2011). Faktor Penyebab Anak Bekerja Dan Upaya Pencegahannya (Studi Pada Pekerja Anak Sektor Informal di Kota Kediri). Jurnal IImu Hukum REFLEKSI HUKUM, 5, 11-43. http://jnk.phb.ac.id/index.php/jnk/articl e/view/374

Faber, B., Krause, B., \& Sanchez de la Sierra, R. (2017). Artisanal Mining, Livelihoods, and Child Labor in the Cobalt Supply Chain of the Democratic Republic of Congo.

Fahlevi, M. (2020). Economic Analysis of Child Labor Based Households. Open Journal for Research in Economics, 3(1), 21-32. https://doi.org/10.32591/coas.ojre.030 $1.03021 f$

Fithriani, R. (2012). Pekerja Anak, Kemiskinan, dan Nilai Ekonomi Anak, Studi Kasus Provinsi Lampung Tahun 2011. Child Poverty and Social Protection Conference, 1-20.

Handy, F., \& Soedjatmiko, S. (2016). Masalah Kesehatan dan Tumbuh Kembang Pekerja Anak Jalanan di Jakarta. Sari Pediatri, 5(4), 138. https://doi.org/10.14238/sp5.4.2004.1 38-44

ILO. (2004). Child Labour: A textbook for university students. https://www.ilo.org/wcmsp5/groups/pu blic/--ed norm/documents/publication/wcms 067258.pdf

Izziyana, W. V. (2019). Perlindungan Hukum Bagi Pekerja Anak Di Indonesia. Legal Standing: Jurnal IImu Hukum, 3(2), 103.

https://doi.org/10.24269/ls.v3i2.2078

Kemnaker. (2014). Peta Jalan (Roadmap) Menuju Indonesia Bebas Pekerja Anak Tahun 2022. Kementerian Tenaga Kerja.

https://www.ilo.org/jakarta/whatwedo/

Jurnal IImu Sosial dan Humaniora | 319 
publications/WCMS_377169/lang-en/index.htm

Komalasari, Y. (2017). Nilai Tambah Wanita Karier Bali Sebagai Sosok Pelestari Budaya. In Prosiding Seminar Nasional AMI.

Lal, B. S. (2019). Child Labour in India: Causes and Consequences. International Journal of Science and Research (IJSR), 8(5), 2199-2206. https://doi.org/10.21275/ART2019845 8

Piri, M. T. (2013). Perlindungan Hukum Terhadap Tindakan Eksploitasi Anak (Kajian Undang-Undang Nomor 23 Tahun 2002). Lex Administratum, 1(2), 25-41.

Purwoko, T. (2013). Analisis Faktor-Faktor Penyebab Keberadaan Anak Jalanan. EJournal Sosiologi, 1(4), 13-25.

Rizkianto, R., Muflikhati, I., \& Hernawati, N. (2015). Nilai Ekonomi Anak, Motivasi, Dan Self-Esteem Pekerja Anak. 6(3), 172-179.

Rusmusi, I., \& Maghfira, A. N. (2018). Pengaruh modal, jam kerja dan lama usaha terhadap pendapatan pedagang. Jurnal Ekonomi, Bisnis Dan Akuntansi (JEBA), 20(04), 1-9. www.jp.feb.unsoed.ac.id/index.php/je ba/article/viewFile/1144/1274

Saleh, S., Akhir, M., \& B, S. (2019). Eksploitasi Pekerja Anak Pemulung. Equilibrium: Jurnal Pendidikan, 6(1), 10-20.

https://doi.org/10.26618/equilibrium.v6 i1.1793

Subekti, R. P. (2018). Urgensi Ratifikasi Konvensi International Labor Organization: Perspektif Perlindungan Pekerja Anak Pada Sektor Rumah Tangga. Jurnal Magister Hukum Udayana (Udayana Master Law Journal), $\quad 7(1), \quad 24$. https://doi.org/10.24843/jmhu.2018.v0 7.i01.p03

Suryati, D., \& Suryaningsih, E. (2015). Analisis Pengaruh Kondisi Sosial
Ekonomi Keluarga Terhadap Pekerja Anak di Kabupaten Lombok Barat. Ganec Swara, 9(1), 29-35.

Syaifudin, N., \& Andini, A. (2020). Pekerja anak di indonesia masih jauh dari nol. Lokadata.

https://lokadata.id/artikel/pekerjaanak-di-indonesia-masih-jauh-dari-nol

Tang, C., Zhao, L., \& Zhao, Z. (2018). Child labor in China. In China Economic Review (Vol. 51). https://doi.org/10.1016/j.chieco.2016.0 5.006

Thiong'o, J. M. (2020). University of Nairobi Modeling The Key Determinant of Child Labour In Kenya School of Mathematics (Issue 0037).

Uppun, P. (2016). Faktor Determinan Pekerja Anak Di Wilayah Perkotaan Sulawesi Selatan Determinant Factors of Child Labor at Urban Areas of South Sulawesi. Jurnal Analisis, 5(1), 85-90.

US Bureau for Labor Statistics. (2020). Employed and unemployed full- and part-time workers by age, sex, race, and Hispanic or Latino ethnicity. http://www.bls.gov/cps/cpsaat08.pdf

Wardana, L. O., \& Sari, L. K. (2020). Analisis Faktor-Faktor Yang Memengaruhi Eksploitasi Pekerja Anak Di Indonesia Menggunakan Regresi Logistik Biner. Indonesian Journal of Statistics and Its Applications, $4(3)$. https://doi.org/10.29244/ijsa.v4i3.616

Webbink, E., Smits, J., \& de Jong, E. (2013). Household and Context Determinants of Child Labor in 221 Districts of 18 Developing Countries. Social Indicators Research, 110(2), 819-836. https://doi.org/10.1007/s11205-0119960-0

Yanti, N. (2014). Keluhan Kesehatan Dan Gangguan Muskuloskeletal Pada Pekerja Tukang Suun Di Pasar Badung Tahun 2013. Community Health, 2(1), 85-95.

Yulianingsih, A., \& Purwanto, I. W. N. (2019). Pengaturan Terhadap

Jurnal IImu Sosial dan Humaniora | 320 
I Made Juli Ardana | Peluang Anak-Anak Bekerja Menurut Karakteristik Anak, Rumah Tangga, dan Kepala Rumah Tangga di Bali

Perlindungan Pekerja Anak Menurut Hukum Positif Indonesia. Kertha Negara: Journal Ilmu Hukum, 7(12), $1-16$. 